\title{
Moderately low nitrogen application mitigate the negative effects of salt stress on annual ryegrass
}

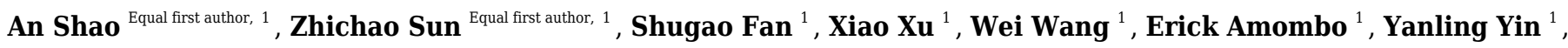 \\ Xiaoning Li ${ }^{1}$, Guangyang Wang ${ }^{1}$, Hongli Wang ${ }^{1}$, Jinmin Fu ${ }^{\text {Corresp. } 1}$ \\ ${ }^{1}$ Coastal Salinity Tolerant Grass Engineering and Technology Research Center, Ludong University, Yantai, China \\ Corresponding Author: Jinmin Fu \\ Email address: turfen@qq.com
}

Appropriate application of nitrogen ( $\mathrm{N}$ ) can alleviate the salt stress-induced damage on plants. This study explores the changes of nitrogen requirement in feeding annual ryegrass seedlings under mild salt concentrations (50 mM, $100 \mathrm{mM}$ ) plus its underlying mitigation mechanism. Results showed that low salt concentration decreased $\mathrm{N}$ requirement as observed from the increment in plant height and biomass at a relative low $\mathrm{N}$ level $(2.0 \mathrm{mM}$ not $5.0 \mathrm{mM}$ ). Under salt treatment, especially at $50 \mathrm{mM} \mathrm{NaCl}$, the OJIP (Chl a fluorescence induction transient) curve and a series of performance indexes $\left(\mathrm{PI}_{\mathrm{ABS}}, \mathrm{RC} / \mathrm{CS}_{0}, \mathrm{ET}_{0} / \mathrm{CS}_{0}, \phi \mathrm{E}_{0}\right.$, $\left.\phi_{0}\right)$ peaked whereas $\mathrm{DI}_{0} / \mathrm{RC}, \mathrm{V}_{\mathrm{j}}$ and $\mathrm{M}_{0}$ were the lowest under moderately low $\mathrm{N}$ level (2.0 $\mathrm{mM})$. In addition, under salt stress, moderately low $\mathrm{N}$ application could maintain the expression of NR (nitrate reductase) and GS (glutamine synthetase) encoding genes at a relatively stable level but had no effect on the expression of detected NRT (nitrate transporter) gene. The seedlings cultured at $2.0 \mathrm{mM} \mathrm{N}$ also exhibited the highest activity of CAT and POD antioxidant enzymes and the lowest MDA content and EL under relative low level of salt treatment. These results indicated that mild salt treatment of annual ryegrass seedlings might reduce $\mathrm{N}$ requirement while moderately low $\mathrm{N}$ application could promote their growth via regulating photosynthesis, alleviating ROS-induced (reactive oxygen species) damage and maintenance of $\mathrm{N}$ metabolism. These results also can provide useful reference for nitrogen application in moderation rather than in excess on annual ryegrass in mild or medium salinity areas through understanding the underlying response mechanisms. 
1 Moderately low nitrogen application mitigate the negative effects of salt stress on annual

2 ryegrass seedlings

3 An Shao ${ }^{1}$, Zhichao Sun ${ }^{1}$, Shugao Fan ${ }^{1}$, Xiao Xu ${ }^{1}$, Wei Wang ${ }^{1}$, Erick Amombo ${ }^{1}$, Yanling Yin ${ }^{1}$, 4 Xiaoning $\mathrm{Li}^{1}$, Guangyang Wang ${ }^{1}$, Hongli Wang ${ }^{1}$ and Jinmin $\mathrm{Fu}^{1}$

$6{ }^{1}$ Coastal Salinity Tolerant Grass Engineering and Technology Research Center, Ludong 7 University, Yantai, Shandong, P.R. China

8

9 Corresponding Author:

10 Jinmin $\mathrm{Fu}$

11 No. 186, Hongqi Middle Road, Zhifu District, Yantai, Shandong, 264025, China

12 Email address: turfen@qq.com 


\section{Abstract}

18 Appropriate application of nitrogen $(\mathrm{N})$ can alleviate the salt stress-induced damage on plants.

19 This study explores the changes of nitrogen requirement in feeding annual ryegrass seedlings

20 under mild salt concentrations $(50 \mathrm{mM}, 100 \mathrm{mM})$ plus its underlying mitigation mechanism.

21 Results showed that low salt concentration decreased $\mathrm{N}$ requirement as observed from the

22 increment in plant height and biomass at a relative low $\mathrm{N}$ level $(2.0 \mathrm{mM}$ not $5.0 \mathrm{mM})$. Under salt

23 treatment, especially at $50 \mathrm{mM} \mathrm{NaCl}$, the OJIP (Chl a fluorescence induction transient) curve and

24 a series of performance indexes $\left(\mathrm{PI}_{\mathrm{ABS}}, \mathrm{RC} / \mathrm{CS}_{0}, \mathrm{ET}_{0} / \mathrm{CS}_{0}, \phi \mathrm{E}_{0}, \phi_{0}\right)$ peaked whereas $\mathrm{DI}_{0} / \mathrm{RC}, \mathrm{V}_{\mathrm{j}}$

25 and $\mathrm{M}_{0}$ were the lowest under moderately low $\mathrm{N}$ level $(2.0 \mathrm{mM})$. In addition, under salt stress,

26 moderately low $\mathrm{N}$ application could maintain the expression of NR (nitrate reductase) and GS

27 (glutamine synthetase) encoding genes at a relatively stable level but had no effect on the expression of detected NRT (nitrate transporter) gene. The seedlings cultured at $2.0 \mathrm{mM} \mathrm{N}$ also exhibited the highest activity of CAT and POD antioxidant enzymes and the lowest MDA content and EL under relative low level of salt treatment. These results indicated that mild salt treatment of annual ryegrass seedlings might reduce $\mathrm{N}$ requirement while moderately low $\mathrm{N}$ application could promote their growth via regulating photosynthesis, alleviating ROS-induced (reactive oxygen species) damage and maintenance of $\mathrm{N}$ metabolism. These results also can provide useful reference for nitrogen application in moderation rather than in excess on annual ryegrass in mild or medium salinity areas through understanding the underlying response mechanisms. 
Introduction

Feeding annual ryegrass (Lolium multiflorum Lam.) is an important forage grass with high

yield, good palatability and high nutritive value (Castanheira et al., 2014). Salt stress is one of

the major abiotic factors that limit annual ryegrass growth and productivity. The adverse effects of salt stress on plants include ionic toxicity, osmotic stress and secondary stresses, such as a decline in photosynthesis, oxidative stress and nutritional disorders (Allakhverdiev \& Murata, 2004; Kalaji et al., 2011; Zhu, 2001). The forage quality such as crude protein, organic matter can be adversely affected by elevated salinity (Ibrahim et al., 2018; Robinson et al., 2004). In response, through long term evolution, plants have adopted a series of response mechanisms to resist and minimize salt stress-induced damage (Deinlein et al., 2014; Zhao et al., 2020). For example, in response to salt-induced oxidative stress, a series of antioxidant enzymes were induced to scavenge excessively produced reactive oxygen species (ROS) (Kohler et al., 2009; Bady et al., 2010), such as superoxide dismutase (SOD), peroxidase (POD), and catalase (CAT) (Apel \& Hirt, 2004; Dong et al., 2001). application is the most effective method of improving plant growth under salt stress. The mainly

54 available inorganic $\mathrm{N}$ forms are ammonium $\mathrm{N}\left(\mathrm{NH}_{4}^{+}\right)$and nitrate $\mathrm{N}\left(\mathrm{NO}_{3}^{-}\right)$, which are transported by AMT (Ammonium transporter) and NRT (Nitrate transporter) respectively 
57 several enzymes such as nitrate reductase (NR), glutamine synthetase (GS) and glutamine 2-

58

oxoglutarate aminotransferase (GOGAT) (Xu et al., 2012). Salt stress has also proved to inhibit the activity of many enzymes such as NR and GS/GOGAT, involved in N assimilation in maize (Zea mays), cowpea (Vigna unguiculata) mung bean (Vigna radiata), tomato (Solanum lycopersicum) and rice (Oryza sativa) (Chakrabarti \& Mukherji, 2007; Debouba et al., 2007; Khan \& Srivastava, 1998; Parul et al., 2015; Silveira et al., 2001; Wang et al., 2012), and then decreased the absorption and utilization of N in plants (Singh et al., 2016). Increased salinity was also reported to significantly reduce nitrogen use efficiency (Murtaza et al., 2013). On the contrary, some studies showed that processes related to $\mathrm{N}$ uptake and assimilation in some plant species were stimulated under certain levels of salt stress. For instance, salt could induce the expression level of nitrate transporter genes such as McNRT1 (Popova et al., 2003). Under salt exposure, the nitrate uptake rate and activity of NR were promoted in glasswort (Salicornia europaea) (Nie et al., 2015). Thus, it has been speculated that the alteration of plant $\mathrm{N}$ nutrition level may hold great promise for regulating salinity response in different species under certain salt level (Chen et al., 2014).

and correcting nutritional imbalances in higher plants (Esmaili et al., 2008; Gómez et al., 1996; Mansour, 2000; Villa et al., 2003). Several N-containing compounds were accumulated in plants that were subjected to salt stress (Dluzniewska et al., 2007; Ehlting et al., 2007; Sudmalis et al., 2018). The accumulates were then reported to participate in osmotic adjustment, promotion of 
77 photosynthetic capacity and mitigation of oxidative stress by scavenging excessive ROS

78 (Homaee et al., 2002; Mansour, 2000; Rontein et al., 2002; Song et al., 2006; Todorova et al.,

79 2013). Although many studies have shown that $\mathrm{N}$ plays an important role in the amelioration of

80 salt stress, it has been confirmed that the alleviation of salt inhibition from $\mathrm{N}$ application shows

81 concentration effects. For example, at the higher salinity levels, increasing the $\mathrm{N}$ content was

82 found to be ineffective in resisting negative influences caused by the enhanced salt

83 concentrations in tomato (Papadopoulos \& Rendig, 1983). Another previous study reported that

84 low levels of $\mathrm{N}$ could mitigate the negative effects whereas high $\mathrm{N}$ levels may exacerbate the

85 detrimental effects of salt stress on photosynthetic rate of chickpea leaves (Soussi et al., 1998).

86 A recent study also found that, low to moderate $\mathrm{N}$ application could mitigate the adverse effects,

87 while excessive $\mathrm{N}$ could elevate the negative effects of salt stress on cotton growth (Chen et al.,

88 2010). In maize, reduction in $\mathrm{N}$ application could not cause additional damage on plant

89 development under salt stress based on reductions in evapotranspiration (Lacerda et al., 2016).

90 Other studies also pointed out that excessive nitrogen fertilization under high salinity levels

91 might lead to more pronounced osmotic effect which in turn provokes the negative effect on crop

92 yield (Beltrão et al., 2002). In addition, in highly saline soils, excessive application of $\mathrm{N}$

93 fertilizer will trigger secondary soil salinization, which in turn adversely affects crop growth

94 (Chen et al., 2010). Moreover, over fertilization with $\mathrm{N}$ may contribute to $\mathrm{N}$ leaching in the

95 saline soil, where plants are unable to utilize the supplied $\mathrm{N}$ fertilizer efficiently and leading to

96 groundwater pollution (Pessarakli \& Tucker, 1998; Shenker et al., 2003, Ward, 2013). 
Therefore, $\mathrm{N}$ requirements for plants under saline environment might be inconsistent with those in normal environment. The difference might be attributed to distinct physical and chemical properties of growth medium and the alteration of plants nitrogen use efficiency plus other physiological response. Hence, in order to minimize the negative effects of salinity as well pollution of underground water, proper $\mathrm{N}$ fertilizer management in plants is necessary for different salt conditions. A previous study on annual ryegrass reported that increasing $\mathrm{N}$ concentration in the nutrient solution enhanced shoot biomass production under relatively high salinity levels (Sagi et al., 1997). However, at relatively low salt concentrations, the optimization of nitrogen demand and the possible mechanisms underlying this alleviation in annual ryegrass are still not fully explored. Based on the above studies, the objectives of this work were to assess the optimal $\mathrm{N}$ level under relatively low salt level and to investigate the possible salt stressalleviatory mechanisms by analyzing physiological indexes and metabolism of $\mathrm{N}$ in annual ryegrass seedlings.

\section{Materials and Methods}

\section{Plant materials and growth conditions}

Annual ryegrass seeds were thawed in plastic pots that were filled with plant growth medium and then cultured in the greenhouse under natural sunlight. After one month, the seedlings were then transferred into Erlenmeyer flasks containing $585 \mathrm{~mL}$ of nutrient solution. The seedlings were then mowed to a height of $12.5 \mathrm{~cm}$ before the treatments were initiated. The experiment was set as control $(0 \mathrm{mM} \mathrm{NaCl})$ and $\mathrm{NaCl}$ treatment $(50 \mathrm{mM}$ or $100 \mathrm{mM})$. Both the control and $\mathrm{NaCl}$ 
117 regimes included different nitrogen application level (using $\mathrm{NH}_{4} \mathrm{NO}_{3}$ as nitrogen source). The

118 hydroponic culture media was processed in a growth chamber under the following conditions:

$11922 / 18^{\circ} \mathrm{C}$ (day/night), 65\% relative humidity, $300 \mu \mathrm{mol} \mathrm{m}^{-2} \mathrm{~s}^{-1}$ photons and a 16-h day/8-h night

120 cycle. The culture solution was refreshed every two days.

121 Chlorophyll $a$ fluorescence transient and the JIP-Test

122 A pulse amplitude modulation fluorometer (PAM2500, Heinz Walz GmbH) was used to measure

123 the chlorophyll a fluorescence transient. In brief, the annual ryegrass leaves were put in dark

124 place for $30 \mathrm{~min}$, and the leaves were then exposed to $3,000 \mu \mathrm{mol}$ photons $\mathrm{m}^{-2} \mathrm{~s}^{-1}$ red light

125 condition. Each treatment consisted of at least three replicates. Based on the theory of energy

126 fluxes in biofilm, the JIP test can further translate the primary data into other biophysical

127 parameters (Force et al., 2003). Hence, the basic parameters were used to calculate a series of

128 parameters (Yusuf et al., 2010).

129 Chlorophyll content and electrolyte leakage

130 The SPAD 502 Plus Chlorophyll Meter (SPAD-502Plus, Spectrum Technologies, Inc., USA)

131 was used to quantify the leaf chlorophyll content. The electrolyte leakage (EL) was measured

132 according to the previous method (Blum \& Ebercon, 1981).

\section{Enzymes activity and lipid peroxidation}

134 Fully expanded of $0.3 \mathrm{~g}$ leaves were immediately grounded into powder with liquid N. $4 \mathrm{~mL}$ ice-

135 cold phosphate buffer $(50 \mathrm{mM}, \mathrm{pH} 7.8)$ was added into the powder and the samples were 
136

137 138 study (Fu \& Huang, 2001).

centrifuged at $12,000 \mathrm{rpm}$ for $20 \mathrm{~min}$ at $4^{\circ} \mathrm{C}$. The supernatant was collected to measure the activity of POD and CAT and the content of MDA based on the method as described by previous

139

140

141

142

143

144 145 applied for gene expression level analysis.

\section{Quantitative RT-PCR Analysis}

The total RNA was isolated and reverse transcribed using the RNeasy kit (Qiagen) and TaqMan reverse transcription kit (Applied Biosystems). Quantitative real-time RT-PCR analysis was conducted using SYBR Green real-time PCR master mix (Toyobo, Japan) and ABI real-time PCR system (Applied Biosystems, FosterCity, CA). The primers used are listed in Supplemental Table S1. The ryegrass Actin gene was used as an inner control, and comparative Ct method was

\section{Statistical Analysis}

One-way ANOVA was performed using SPSS17.0 for Windows (SPSS). All of above tests had

148 at least three independent replicates. Results were expressed as mean $\pm S D$, and letters show 149 significant differences $(P<0.05)$ by Student's $t$-test..

\section{Results}

Effect of different $\mathrm{N}$ level treatment on the growth of annual ryegrass seedlings under $\mathrm{NaCl}$

152 stress

153 Under control condition, the plant height and the relative increase of biomass of annual ryegrass 
154 seedlings peaked under $5.0 \mathrm{mM} \mathrm{N}$, and then slightly declined under $10 \mathrm{mM} \mathrm{N}$. As compared to $1555.0 \mathrm{mM} \mathrm{N}$, the height of seedlings grown under $2.0 \mathrm{mM} \mathrm{N}$ and $10 \mathrm{mM} \mathrm{N}$ declined by about $10 \%$ 156 and $15 \%$ respectively (Fig. 1A, B). However, under $50 \mathrm{mM}$ or $100 \mathrm{mM} \mathrm{NaCl}$ treatment, the plant 157 height reached maximum under $2.0 \mathrm{mM} \mathrm{N}$ and then declined slightly under $5.0 \mathrm{mM} \mathrm{N}$. In 158 addition, salt treatment dramatically reduced the height of plants grown under $5.0 \mathrm{mM}$ or $10 \mathrm{mM}$ $159 \mathrm{~N}$ compared with their respective control plants. However, under $2.0 \mathrm{mM} \mathrm{N}$ condition, the plant height had no significant difference with or without salt treatment (Fig. 1B). When exposed to 50 $\mathrm{mM} \mathrm{NaCl}$, the relative increase of biomass had no significant difference among different $\mathrm{N}$ levels. After the plants were exposed to $100 \mathrm{mM} \mathrm{NaCl}$ for 10 days, the biomass only increased when $2.0 \mathrm{mM} \mathrm{N}$ was applied whereas the biomass decreased when extra nitrogen $(5.0$ or $10 \mathrm{mM}$ N) was applied (Fig. 1C). These similar alteration trends in biomass and plant height suggested that salt stress might change the $\mathrm{N}$ requirement of annual ryegrass and moderately reducing $\mathrm{N}$ application might alleviate the inhibitory effect of salt stress on annual ryegrass seedlings growth. In order to investigate whether ultra-low $\mathrm{N}$ treatment still had a moderating function on the growth of annual ryegrass seedlings under salt stress, we added a lower concentration $(0.5 \mathrm{mM})$ of $\mathrm{N}$ treatment and conducted another experiment. The results showed that the plant height of annual ryegrass seedlings achieved maximum under $5.0 \mathrm{mM} \mathrm{N}$ without salt treatment. However, when exposed to $50 \mathrm{mM}$ or $100 \mathrm{mM} \mathrm{NaCl}$, the plant height reached maximum under $2.0 \mathrm{mM} \mathrm{N}$ 172 (Fig. S1A, B), showing the similar tendency with the first experiment (Fig. 1A, B). In addition, without $\mathrm{NaCl}$ treatment, there was no significant difference of plant height when seedlings were supplemented with lower $\mathrm{N}$ concentration $(0.5 \mathrm{mM}$ or $2.0 \mathrm{mM})$. However, under $\mathrm{NaCl}$ treatment, 
175 the plant height was significantly increased under $2.0 \mathrm{mM} \mathrm{N}$ compared with $0.5 \mathrm{mM} \mathrm{N}$ (Fig. S1).

176 The results of these two experiments at different times together confirmed that the alleviatory

177 effect of $\mathrm{N}$ application on the growth inhibition of annual ryegrass under salt stress might have a

178 certain range. Moderately low $\mathrm{N}$ could alleviate the inhibition of annual ryegrass growth by salt

179 stress through a series of response mechanisms, whereas ultra-low $\mathrm{N}$ could not promote, but

180 seriously inhibit the growth of annual ryegrass.

181

182

183

184

185

186

187

188

189

190

191

192

193

194

\section{Impact of $\mathrm{N}$ on the OJIP transient curve in the leaves of annual ryegrass under $\mathrm{NaCl}$ stress}

In order to decipher the effect of moderate N-mediated alleviation of salt stress on annual ryegrass, the impact of $\mathrm{N}$ levels on photochemistry of photosystem II (PS II) of $\mathrm{NaCl}$ treated annual ryegrass seedlings were determined through chlorophyll a fluorescence transient-JIP test.

The step $\mathrm{O}$ to $\mathrm{J}$ represents the reduction process of $\mathrm{Q}_{\mathrm{A}}$ by PSII. Due to the brimming of the plastoquinone pool, the curve then rose to I phase. The step I to P was an account for the blockage of electron transfer to the acceptor side of PSI. Under control condition, the fluorescence of I and P phase of seedlings leaves grown with $2.0 \mathrm{mM} \mathrm{N}$ or $5.0 \mathrm{mM} \mathrm{N}$ was stronger than that grown with $0.5 \mathrm{mM} \mathrm{N}$ (Fig. 2A). However, after $\mathrm{NaCl}$ exposure, the chlorophyll fluorescence curve of annual ryegrass leaves grown with $2.0 \mathrm{mM}$ N from I to P step was higher than that under $0.5 \mathrm{mM}$ or $5.0 \mathrm{mM} \mathrm{N}$ (Fig. 2B, C). In particular, the OJIP curve was much higher when plants exposed to relatively low $\mathrm{NaCl}$ treatment $(50 \mathrm{mM})$ under $2.0 \mathrm{mM} \mathrm{N}$ level compared to other two $\mathrm{N}$ levels (Fig. 2C). The results suggested that deficient or excessive nitrogen application under salt stress might lead to the photosynthetic electron transport traffic 
195 196 197 198 199 200

jam, especially beyond $\mathrm{Q}_{\mathrm{A}}{ }^{-}$. In addition, under $\mathrm{NaCl}$ treatment, the leave chlorophyll content of the plants grown with $2.0 \mathrm{mM}$ and $5.0 \mathrm{mM} \mathrm{N}$ was significantly higher than that grown with 0.5 $\mathrm{mM}$ N. However, there was no significant difference in the chlorophyll content between $2.0 \mathrm{mM}$ and 5.0 $\mathrm{mM} \mathrm{N}$-supplied plants (Fig. 2D).

\section{Impact of $\mathrm{N}$ on Chlorophyll fluorescence parameters in the leaves of ryegrass under $\mathrm{NaCl}$}

\section{stress}

The chlorophyll fluorescence parameters were used to quantify the photosynthetic behavior of the samples. Under the control condition, the $\mathrm{PI}_{\mathrm{ABS}}$ value, which represents the overall activity of PSII, increased with the $\mathrm{N}$ level, and peaked under $5.0 \mathrm{mM} \mathrm{N}$ (Fig. 3A). However, under $50 \mathrm{mM}$ or $100 \mathrm{mM} \mathrm{NaCl}$ treatment, the $\mathrm{PI}_{\mathrm{ABS}}$ value under $2.0 \mathrm{mM} \mathrm{N}$ were higher than that under other $\mathrm{N}$ levels (Fig. 3B, C). The variable fluorescence at $J$ phase $\left(V_{j}\right)$ and the relative speed of $Q_{A}$ deoxidation $\left(\mathrm{M}_{0}\right)$ of NaCl-treated leaves grown with $2.0 \mathrm{mM} \mathrm{N}$ were smaller than those grown with $0.5 \mathrm{mM}$ or $5.0 \mathrm{mM} \mathrm{N}$, and the difference was most significant under $50 \mathrm{mM} \mathrm{NaCl}$ treatment (Fig. 3B). Under normal condition, $\Psi_{0}$ and $\Phi \mathrm{E}_{0}$ had no significant difference among three $\mathrm{N}$ levels (Fig. 3A). When exposed to $50 \mathrm{mM} \mathrm{NaCl}$, the proportion of energy used for photochemical reaction and energy electron transport in leaves $\left(\phi_{0}, \phi \mathrm{E}_{0}\right)$ grown with $2.0 \mathrm{mM} \mathrm{N}$ were larger than those grown with other $\mathrm{N}$ levels, together with greater reaction center density $\mathrm{RC} / \mathrm{CS}_{0}$ and electron-transfer energy $\mathrm{ET}_{0} / \mathrm{CS}_{0}$ and lower $\mathrm{DI}_{0} / \mathrm{CS}_{0}$ (the energy consumed in unit cross-sectional area) (Fig. 3B). However, $\phi \mathrm{P}_{0}$, which represents the maximum quantum yield for primary photochemistry, displayed no changes. When exposed to $100 \mathrm{mM} \mathrm{NaCl}$, the $\mathrm{PI}_{\mathrm{ABS}}$ value 
under $2.0 \mathrm{mM} \mathrm{N}$ was higher than that under other $\mathrm{N}$ levels, whereas the other parameters showed

216 no significant change (Fig. 3C). These results suggested that the optimum amount of $\mathrm{N}$ might promote primary photochemical reactions of PSII, especially under relatively low $\mathrm{NaCl}$ level.

The lipid peroxidation levels and activities of antioxidant enzymes in the leaves of the annual ryegrass seedlings under $\mathrm{NaCl}$ stress

Malondialdehyde (MDA) is one of the products of membrane lipid peroxidation which can be used to assess the degree of the salt-induced damage to plants. The results showed that, in the absence of salt stress, there was no significant difference of MDA content among the three $\mathrm{N}$ levels. When the plants grown under $2.0 \mathrm{mM} \mathrm{N}$ were exposed to a relatively lower $\mathrm{NaCl}$ treatment $(50 \mathrm{mM})$, the MDA content declined significantly compared to the control. In addition, the MDA content of plants grown under higher $\mathrm{N}$ concentration were significantly lower compared to those grown under $0.5 \mathrm{mM} \mathrm{N}$ (Fig. 4A). The electrolyte leakage (EL) in the leaves of ryegrass increased with the increase of $\mathrm{NaCl}$ concentration under all three $\mathrm{N}$ levels. When exposed to $100 \mathrm{mM} \mathrm{NaCl}$, The $\mathrm{EL}$ in the leaves of ryegrass grown under higher $\mathrm{N}$ concentration was significantly lower compared to that grown under $0.5 \mathrm{mM} \mathrm{N}$. Moreover, under $100 \mathrm{mM}$ $\mathrm{NaCl}$ stress, the EL of ryegrass grown under $2.0 \mathrm{mM} \mathrm{N}$ was significantly lower than that grown under 5.0 mM N (Fig. 4B). The lipid peroxidation levels and activities of antioxidant enzymes of the leaves were also determined. With the increase of $\mathrm{NaCl}$ concentration, the CAT enzyme activity rose under all $\mathrm{N}$ levels. Under $\mathrm{NaCl}$ treatments, the $\mathrm{CAT}$ activity of ryegrass seedlings cultured at $2.0 \mathrm{mM} \mathrm{N}$ was the highest compared with that of plants cultured at $0.5 \mathrm{mM} \mathrm{N}$ or 5.0 
$235 \mathrm{mM} \mathrm{N}$ (Fig. 4C). The POD enzyme activity had no obvious regularity with the $\mathrm{N}$ levels.

236 However, when exposed to $50 \mathrm{mM} \mathrm{NaCl}$, the POD activity of seedlings grown under $2.0 \mathrm{mM} \mathrm{N}$

237 was higher than seedlings grown under $5.0 \mathrm{mM} \mathrm{N}$ (Fig. 4D). These results suggested that

238 ryegrass cultured in $2.0 \mathrm{mM} \mathrm{N}$ solution might improve the activities of certain antioxidant

239 enzymes and enhance the salt-tolerance ability of ryegrass, especially at relatively low $\mathrm{NaCl}$

240 level.

241

242

243

244

245

246

247

248

249

250

251

252

253

254

Effect of different $\mathbf{N}$ treatment on the $\mathbf{N}$ content and $\mathbf{N}$ assimilation-related genes under

\section{$\mathrm{NaCl}$ stress}

To investigate the influence of different $\mathrm{N}$ concentrations on $\mathrm{N}$ assimilation under $\mathrm{NaCl}$ stress, we assessed the expression level of $N R$ gene in the leaves of ryegrass. Without $\mathrm{NaCl}$ treatment, the level of the $N R$ expression in the leaves increased with the increase of $\mathrm{N}$ concentration. A reduction in $\mathrm{N}(2.0 \mathrm{mM})$ caused a significant decline in mRNA expression of $N R$ (Fig. 5A), as compared with $5.0 \mathrm{mM} \mathrm{N}$-applied plants. When plants were cultured with 5.0 $\mathrm{mM} \mathrm{N}$, the level of $N R$ gene expression showed a significantly decrease with the increase of salt concentration. However, under $2.0 \mathrm{mM} \mathrm{N}$, the suppression degree of $N R$ expression by salt stress was relatively lower. Compared with $0 \mathrm{mM} \mathrm{NaCl}$, the expression level of $N R$ of $2.0 \mathrm{mM} \mathrm{N}$ supplied plants showed no significant decrease when exposed to $100 \mathrm{mM} \mathrm{NaCl}$ (Fig. 5A). Under the combined treatment of nitrogen and salt, the homolog gene of $G S$ showed a similar expression response pattern with $N R$ (Fig. S2A). The expression of the $N R T$ gene was induced when plants were exposed to a relatively low $\mathrm{NaCl}$ level $(50 \mathrm{mM})$. However, there was no 
255 significant difference in the homolog of one $N R T$ gene expression between plants grown with 5.0

$256 \mathrm{mM} \mathrm{N}$ and $2.0 \mathrm{mM} \mathrm{N}$ under $\mathrm{NaCl}$ treatment (Fig. S2B). When exposed to $\mathrm{NaCl}$, the nitrogen

257 content of leaves grown under $2.0 \mathrm{mM} \mathrm{N}$ or $5.0 \mathrm{mM} \mathrm{N}$ showed a significant decline compared to

258 the control condition, respectively. Without $\mathrm{NaCl}$ treatment, the $\mathrm{N}$ content of ryegrass leaves

259 grown under $5.0 \mathrm{mM} \mathrm{N}$ was higher. However, under salt treatment, the $\mathrm{N}$ content of leaves

260 showed no significant difference between 5.0 $\mathrm{mM} \mathrm{N}$ and $2.0 \mathrm{mM} \mathrm{N}$ application (Fig. 5B).

261

262

263

264

265

266

267

268

269

270

271

272

273

274

\section{Discussion}

Plant response to salt stress is a complex phenomenon that involves both morphological, physiological, and biochemical processes. It has been reported that the application of $\mathrm{N}$ may alleviate salt stress-induced phytotoxicity (Correia et al., 2005; Siddiqui et al., 2012; Singh et al., 2016). Salt stress effect on plants consists of $\mathrm{Na}^{+}$and $\mathrm{Chl}^{-}$ion toxicity, osmotic effects, and nutrient imbalance (Kohler et al., 2009; Shannon, 1997). Nitrogen fertilization plays a critical role on the growth and development of the many plants, and appropriate $\mathrm{N}$ could help to mitigate the damage caused by nutritional imbalances due to saline irrigation (Al-Rawahy et al., 1992; Borzouei et al., 2014; Fan et al., 2015; Duan et al., 2017). However, related researches showed that rather than $\mathrm{N}$ alone, plant growth was significantly affected by the interaction between soil salinity and N (Papadopoulos \& Rendig, 1983; Chen et al., 2010). In this experiment, exogenous $\mathrm{N}$ application of $\mathrm{N}$ to annual ryegrass seedlings significantly increased the in planta $\mathrm{N}$ content, plant height and the biomass, but there was a concentration effect. In the absence of exogenous salt, the increment of plant height and biomass was directly proportional to the $\mathrm{N}$ level, and 
peaked at $5.0 \mathrm{mM} \mathrm{N}$. However, after exposure to $\mathrm{NaCl}$, the plant height and the relative increase

276 of biomass peaked at the $\mathrm{N}$ level of $2.0 \mathrm{mM}$ (Fig.1). Moreover, ultra-low $\mathrm{N}$ seriously inhibited

277 the growth of ryegrass under both control and salt conditions (Fig. S1). These results were consistent with results detected in cotton (Chen et al., 2010). Also a previous study on annual ryegrass reported that increasing $\mathrm{N}$ application could promote shoot growth under under salt concentrations of $2.0 \mathrm{dS} / \mathrm{m}$ (below $20 \mathrm{mM}$ ) and $11.2 \mathrm{dS} / \mathrm{m}$ (over $100 \mathrm{mM}$ ) (Sagi et al., 1997).

However, we noticed that moderate reduction of $\mathrm{N}$ application had a maximum promotion effect on plant growth. The salt concentration used for our treatments are $50 \mathrm{mM}$ and $100 \mathrm{mM}$, which are different from the salt concentration used in Sagi's experiments. This difference may be attributed to different culture conditions as well as levels of salinity. In this study, we focus mainly on the optimization of nitrogen application at lower salt concentration. Moreover, $\mathrm{N}$ content was also positively correlated with the amount of $\mathrm{N}$ applied which peaked at the $\mathrm{N}$ level of $5.0 \mathrm{mM}$ without salt treatment. However, under salt treatments, there was no significant difference in $\mathrm{N}$ content of ryegrass leaves between $5.0 \mathrm{mM}$ and $2.0 \mathrm{mM} \mathrm{N}$ application (Fig. 5B). External cues such as salt can stimulate the production of ROS which can further damage lipids in plant cells (Kohler et al., 2009). Accumulation of N-containing compounds has been reported to participate in salt response such as osmotic adjustment and ROS scavenging (Dluzniewska et al., 2007; Ehlting et al., 2007; Homaee et al., 2002; Mansour, 2000; Song et al., 2006; Sudmalis et al., 2018). In this study, by reducing MDA content and elevating certain antioxidant enzyme activities, moderately low $\mathrm{N}$ application could reduce the damage to the membrane of ryegrass seedlings caused by salt stress, especially at relatively low $\mathrm{NaCl}$ treatment. Together, these 
296 results indicated that saline habitats might change the $\mathrm{N}$ requirement of ryegrass seedlings.

297 Excessive or ultra-low $\mathrm{N}$ applications both have counter effects on the growth or salt resistance

298 of annual ryegrass under low level of salt stress. the primary reaction alternations of PSII, which is more sensitive than photosystem I (PS I). To investigate PSII behaviors in O-J-I-P transient, JIP test is always used to quantify the derived photochemical parameters (Apostolova et al., 2006; Sayed, 2003; Stirbet et al., 2014). In this study, after exposure to $\mathrm{NaCl}$, the nitrogen application level had a significant effect on fluorescent transients, especially the J and P steps (Fig. 2). N deficiency and $\mathrm{N}$ over application under salt stress might lead to the photosynthetic electron transport traffic jam, especially beyond $\mathrm{Q}_{\mathrm{A}}{ }^{-}$(Fig. 2B, C). With the increase of $\mathrm{N}$ level, the $\mathrm{PI}_{\mathrm{ABS}}$, which could accurately reflect the state of plant photosynthetic apparatus, increased without $\mathrm{NaCl}$ treatment (Fig. 2A), indicating that $\mathrm{N}$ could promote the primary photochemical reactions of PSII in the waterside. However, under salt stress, excessive or deficient $\mathrm{N}$ application slowed down the promotion of the primary photochemical reaction of the PSII (Fig. 2B, C). In addition, the accumulated amount of $\mathrm{Q}_{\mathrm{A}}{ }^{-}\left(\mathrm{V}_{\mathrm{j}}\right)$ and the relative speed of $\mathrm{Q}_{\mathrm{A}}$ deoxidation $\left(\mathrm{M}_{0}\right)$ (Strasser, 1997; Strasserf \& Srivastava, 1995;

312 Force et al., 2003) of plants grown under moderately low $\mathrm{N}$ were lower than those grown under 313 other $\mathrm{N}$ conditions, indicating that leaves grown under moderate $\mathrm{N}$ level have a higher electron 314 transport rate between $\mathrm{Q}_{\mathrm{A}}$ and $\mathrm{Q}_{\mathrm{B}}$, thus reducing the accumulation amount of $\mathrm{Q}_{\mathrm{A}}{ }^{-}$and increasing 315 the photochemical reaction efficiency (Allakhverdiev \& Murata, 2004). The increase of $\Psi_{0}$ and 
$316 \Phi \mathrm{E}_{0}$ of plants grown under $2.0 \mathrm{mM} \mathrm{N}$ indicated that leaves use more energy for photochemical

317 reaction and electron-transfer process, thus producing more NADPH for carbon assimilation and

318 confirming that leaves have the optimal energy distribution under certain salt level (Strasser et

319 al., 2004). The leaves of annual ryegrass grown under $2.0 \mathrm{mM} \mathrm{N}$ also had a greater reaction

320 center density $\mathrm{RC} / \mathrm{CS}_{0}$ and higher $\mathrm{ET}_{0} / \mathrm{CS}_{0}$ but lower $\mathrm{DI}_{0} / \mathrm{CS}_{0}$ than those grown under other $\mathrm{N}$

321 conditions. This pattern indicated that the specific activity of a unit cross-sectional area of leaves

322 grown under moderately low $\mathrm{N}$ was stronger than that grown under other $\mathrm{N}$ conditions, reducing

323 the energy burden of a unit reaction center. We also noticed that, under the lowest $\mathrm{NaCl}$

324 treatment $(50 \mathrm{mM})$, the application of $2.0 \mathrm{mM} \mathrm{N}$ had the best effect on alleviating salt stress.

325 Under $50 \mathrm{mM} \mathrm{NaCl}$ treatment, the physiological indexes of annual ryegrass seedlings seemed to

326 be less affected, and therefore the seedlings might be more sensitive to the promotion of nitrogen

327 application. Thus, we proposed that the optimum amount of $\mathrm{N}$ might promote primary

328 photochemical reactions of PSII under certain level of $\mathrm{NaCl}$ treatment.

After absorption as ammonia, $\mathrm{N}$ can be directly assimilated by plants. While after absorption as nitrate, $\mathrm{N}$ must first be reduced by nitrate reductase and sub-acid reductase enzymes. NR can reduce nitrate $\mathrm{N}$ to ammonium, which has also has important effects on

332 photosynthesis and other processes related to $\mathrm{N}$ metabolism (Xu et al., 2012). Reports have 333 shown that $\mathrm{NO}_{3}{ }^{-}$has a significant effect on the induction of $\mathrm{NR}$ expression. From this experiment, 334 under control condition, the level of $N R$ gene expression in leaves increased with the increase of $335 \mathrm{~N}$ concentration (Fig. 5A, B), which is consistent with the previous reports (Oaks, 1993). 
336 However, when the seedlings were treated with $\mathrm{NaCl}$, the $N R$ expression level was significantly

337 declined at a higher $\mathrm{N}$ level $(5.0 \mathrm{mM})$. On the contrary, at a moderately low $\mathrm{N}$ level $(2.0 \mathrm{mM})$,

338 the $N R$ expression level is relatively low without $\mathrm{NaCl}$ treatment, but the degree of reduction is

339 moderate when exposed to $\mathrm{NaCl}$. The $G S$ gene expression displayed a similar trend with the $N R$

340 gene under the interaction between salt and nitrogen conditions, indicating an interactive

341 response mechanism between $\mathrm{N}$ assimilation-related genes (Fig. S2A). Therefore, it can be

342 observed that moderate $\mathrm{N}$ application might help annual ryegrass maintain the expression level

343 of $\mathrm{N}$ assimilation-related gene (Fig. 5A) and further maintain the nitrogen content under salt

344 stress (Fig. 5B). However, when excessive $\mathrm{N}$ was applied under salt stress, the $N R$ expression

345 was significantly increased, indicating that $\mathrm{N}$ assimilation was strengthened; it might then

346 compete with photosynthetic carbon for ATP and NADPH and increase the burden of

347 photosynthetic electron transfer. The competition result might lead to a decline in the overall

348 activity of PSII of annual ryegrass $\left(\mathrm{PI}_{\mathrm{ABS}}\right)$ (Fig. 2). Under nitrogen deficiency, the reduced

349 absorption of nitrogen might reduce the consumption of nitrogen assimilation reducing power,

most of which are derived from photosynthesis, thus resulting in the accumulation of chloroplast

NADPH. The over-accumulation of NADPH could inhibit the photosynthetic efficiency and

cause excessive production of ROS (Fig. 3A), leading to increased cell membrane damage,

which may in turn lead to reduced photosynthetic efficiency (Fig. 2B, C, D). Nitrogen is also a constituent of chlorophyll which is not only the most important pigment molecules of photosynthesis involved in energy absorption and transmission but also the essential electron 
357 with the photosynthetic capacity (Grassi et al., 2005; Kattge et al., 2009). Through this 358 experiment, we can deduce that under different salt stress condition, the appropriate addition of $359 \mathrm{~N}$ can increase relative chlorophyll content of plants. However, the relative chlorophyll content 360 is only positively correlated with $\mathrm{N}$ levels within a certain range $(0.5-2.0 \mathrm{mM})$ and should be 361 reduced beyond a certain range (Fig. 2D). The moderately supply of $\mathrm{N}$ under salt stress increased 362 the content of chlorophyll and might increase the light-harvesting ability, partly contributing to 363 the up-regulated photosynthetic performance index. Based on the above studies, it can be seen

364 365 366 367 368 369 that moderately low $\mathrm{N}$ application under low level of salt stress might help annual ryegrass maintain the expression level of $\mathrm{N}$ assimilation-related gene and then maintain the leaf $\mathrm{N}$ content of the plant, which might in turn cause changes in chlorophyll content, further avoiding the negative effect on photosynthetic capacity.

\section{Conclusion}

To investigate the possible mechanism of moderately low nitrogen-mediated alleviation of $\mathrm{NaCl}$ stress, the degree of lipid peroxidation, antioxidant enzyme activity alternation, changes of photosynthesis performance and nitrogen assimilation were analyzed in this study. In summary, under low salt stress, the demand for $\mathrm{N}$ may have declined, while moderately reducing $\mathrm{N}$ application could help to alleviate the salt-induced damage in annual ryegrass mainly by alleviating the damage caused by ROS and promoting the performance of photosynthesis and nitrogen metabolism. Further, in order to enhance plant growth and increase nitrogen use efficiency, the optimum application of nitrogen fertilizer needs to be controlled to match the 
377 plant needs at each growth stage and to adapt to different saline environment.

\section{Acknowledgements}

379 We thank Dr. Yongzhe Ren (Henan Agriculture University) for the valuable advice on the design 380 of the experiments.

381

382

383

384

385

386

387

388

389

390

391

392

393

394

395

\section{Reference}

Allakhverdiev SI, Murata N. 2004. Environmental stress inhibits the synthesis de novo of proteins involved in the photodamage-repair cycle of photosystem II in Synechocystis sp. PCC 6803. Biochimica et Biophysica Acta 1657: 23-32 DOI 10.1016/j.bbabio.2004.03.003.

Al-Rawahy SA, Stroehlein JL, Pessarakli M. 1992. Dry-matter yield and nitrogen-15, $\mathrm{Na}^{+}, \mathrm{Cl}^{-}$, and $\mathrm{K}^{+}$content of tomatoes under sodium chloride stress. Journal of Plant Nutrition 15: 341-358 DOI 10.1080/01904169209364323.

Apel K, Hirt H. 2004. Reactive oxygen species: metabolism, oxidative stress, and signal transduction. Annual Review of Plant Biology 55: 373-399 DOI 10.1146/annurev.arplant. 55.031903 .141701$.

Apostolova EL, Dobrikova AG, Ivanova PI, Petkanchin IB, Taneva SG. 2006. Relationship between the organization of the PSII supercomplex and the functions of the photosynthetic apparatus. Journal of Photochemistry and Photobiology B-biology 83: 114-122 DOI 10.1016/j.jphotobiol.2005.12.012.

Baby J, Jini D. 2010. Insight into the role of antioxidant enzymes for salt tolerance in plants. 
397

398

399

400

401

402

403

404

405

406

407

408

409

410

411

412

413

414

Beltrão J, Jesus SB, Panagopoulos T, Ben Asher J. 2002. Combined effects of salts and nitrogen on the yield function of lettuce. Acta Horticulturae 573: 363-368 DOI 10.17660/ActaHortic.2002.573.43.

Blum A, Ebercon A. 1981. Cell membrane stability as a measure of drought and heat tolerance in wheat. Crop Science 21: 43-47 DOI 10.2135/cropsci1981.0011183X002100010013x.

Borzouei A, Eskandari A, Kafi M, Mousavishalmani A, and Khorasani A. 2014. Wheat yield, some physiological traits and nitrogen use efficiency response to nitrogen fertilization under salinity stress. Indian Journal of Plant Physiology 19: 21-27 DOI 10.1007/s40502014-0064-0.

Castanheira N, Dourado AC, Alves PI, Cortés-Pallero AM, Delgado-Rodríguez AI, Prazeres N, Borges N, Sánchez C, Barreto Crespo MT, Fareleira P. 2014. Annual ryegrass-associated bacteria with potential for plant growth promotion. Microbiological Research 169: 768-779 DOI 10.1016/j.micres.2013.12.010.

Chakrabarti N, Mukherji S. 2007. Effect of phytohormone retreatment on nitrogen metabolism in Vigna radiata under salt stress. Biologia Plantarum 46: 63-66 DOI 10.1023/A:1022358016487.

Chen W, Hou Z, Wu L, Liang Y, Wei C. 2010. Effects of salinity and nitrogen on cotton growth in arid environment. Plant and Soil 326: 61-73 DOI 10.1007/s11104-008-9881-0. 
415

416

417

418

419

420

421

422

423

424

425

426

427

428

429

430

431

432

433

Correia CM, Pereira JMM, Coutinho JF, Lars O. Björn LO, Torres-Pereira JMG. 2005.

Ultraviolet-B radiation and nitrogen affect the photosynthesis of maize: a mediterranean field study. European Journal of Agronomy 22: 337-347 DOI 10.1016/j.eja.2004.05.002.

Debouba M, Maaroufi-Dghimi H, Suzuki A, Ghorbel MH, Gouia H. 2007. Changes in growth and activity of enzymes involved in nitrate reduction and ammonium assimilation in tomato seedlings in response to $\mathrm{NaCl}$ stress. Zentralbl Gynakol 99: 1143-1151 DOI $10.1186 / 1471-2474-8-66$.

Deinlein U, Stephan AB, Horie T, Luo W, Xu G, Schroeder JI. 2014. Plant salt-tolerance mechanisms. Trends in Plant science 19: 371-379 DOI 10.1016/j.tplants.2014.02.001.

Dluzniewska P, Gessler A, Dietrich H, Schnitzler J-P, Rennenberg H. 2007. Nitrogen uptake and metabolism in Populus $\times$ canescens as affected by salinity. New Phytologist 173: 279293 DOI 10.1111/j.1469-8137.2006.01908.x.

Dong HL, Kim YS, Lee CB. 2001. The inductive responses of the antioxidant enzymes by salt stress in the rice (Oryza sativa L.). Journal of Plant Physiology 158: 737-754 DOI 10.1078/0176-1617-00174.

Duan M, and Chang SX. 2017. Nitrogen fertilization improves the growth of lodgepole pine and white spruce seedlings under low salt stress through enhancing photosynthesis and plant nutrition. Forest Ecology \& Management 404:197-204 DOI 10.1016/j.foreco.2017.08.045.

Ehlting B, Dluzniewska P, Dietrich H, Selle A, Teuber M, Hänsch R, Nehls U, Polle A, 
434

435

436

437

438

439

440

441

442

443

444

445

446

447

448

449

450

451

452

Schnitzler J-P, Rennenberg H, Gessler A. 2007. Interaction of nitrogen nutrition and salinity in Grey poplar (Populus tremula $\times$ alba). Plant Cell and Environment 30: 796-811 DOI 10.1111/j.1365-3040.2007.01668.x.

Esmaili E, Kapourchal S, Malakouti M, Homaee M. 2008. Interactive effect of salinity and two nitrogen fertilizers on growth and composition of sorghum. Plant

Soil

and Environment 54: 537-546 DOI 10.1111/j.1365-3059.2008.01912.x.

Fan H, Meng GH, Cheng RR, Li L, Yun X, and Wang BS. 2013. Effect of different nitrogen levels on the photosynthesis and growth of sweet Sorghum Seedlings under Salt Stress. Advanced Materials Research 726-731: 4352-4357 DOI 10.4028/www.scientific.net/ AMR.726-731.4352.

Force L, Critchley C, Rensen JJSV. 2003. New fluorescence parameters for monitoring photosynthesis in plants. Photosynthesis Research 78: 17-33 DOI 10.1023/A: 1026012116709 .

Fu J, Huang B. 2001. Involvement of antioxidant and lipid peroxidation in the adaptation of two cool-season grasses to localized drought stress. Environmental and Experimental Botany 45: 105-114 DOI 10.1016/S0098-8472(00)00084-8.

Gómez I, Pedreño JN, Moral R, Iborra MR, Palacios G, Mataix J. 1996. Salinity and nitrogen fertilization affecting the macronutrient content and yield of sweet pepper plants. Journal of Plant Nutrition 19: 353-359 DOI 10.1080/01904169609365126. 
453 Giagnoni L, Pastorelli R, Mocali S, Arenella M, Nannipieri P, Renella G. 2015. Availability

454 of different nitrogen forms changes the microbial communities and enzyme activities in the rhizosphere of maize lines with different nitrogen use efficiency. Applied Soil Ecology 98: 30-38 DOI 10.1016/j.apsoil.2015.09.004.

457

458

459

460

461

462

463

464

465

466

467

468

469

470

471

Grassi G, Vicinelli E, Ponti F, Cantoni L, Magnani F. 2005. Seasonal and interannual variability of photosynthetic capacity in relation to leaf nitrogen in a deciduous forest plantation in northern Italy. Tree Physiology 25: 349-360 DOI 10.1093/treephys/25.3.349.

Homaee M, Feddes RA, Dirksen C. 2002. A macroscopic water extraction model for nonuniform transient salinity and water stress. Soil Science Society of America Journal 66: 1764-1772 DOI 10.2136/sssaj2002.1764.

Ibrahim M. E. H., Zhu X. K., Zhou G.S., Ali A.Y.A., Ahmad I., Farah G.A., 2018. Nitrogen fertilizer alleviated negative impacts of $\mathrm{NaCl}$ on some physiological parameters of wheat. Pakistan Journal of Botany 50: 2097-2104.

Kalaji HM, Govindjee Bosa K, Kościelniak J, Żuk-Gołaszewska K. 2011. Effects of salt stress on photosystem II efficiency and $\mathrm{CO}_{2}$ assimilation of two Syrian barley landraces. Environmental and Experimental Botany 73, 64-72 DOI 10.1016/j.envexpbot.2010.10.009.

Kattge J, Knorr W, Raddatz T, Wirth C. 2009. Quantifying photosynthetic capacity and its relationship to leaf nitrogen content for global-scale terrestrial biosphere models. Global Change Biology 15: 976-991 DOI 10.1111/j.1365-2486.2008.01744.x. 
472 Khan MG, Srivastava HS. 1998. Changes in growth and nitrogen assimilation in Maize plants 473 induced by $\mathrm{NaCl}$ and growth regulators. Biologia Plantarum 41: 93-99 DOI 10.1023/A:1001768601359.

475

476

477

478

479

480

481

482

483

484

485

486

487

488

489

490

Kohler J, Hernández JA, Caravaca F, Roldán A. 2009. Induction of antioxidant enzymes is involved in the greater effectiveness of a PGPR versus AM fungi with respect to increasing the tolerance of lettuce to severe salt stress. Environmental and Experimental Botany 65: 245-252 DOI 10.1016/j.envexpbot.2008.09.008.

Lacerda CF, Ferreira JFS, Liu X, and Suarez DL. 2016. Evapotranspiration as a criterion to estimate nitrogen requirement of maize under salt stress. Journal of Agronomy and Crop Science 202:192-202. DOI 10.1111/jac.12145

Mansour MMF. 2000. Nitrogen containing compounds and adaptation of plants to salinity stress. Biologia Plantarum 43: 491-500 DOI 10.1023/A:1002873531707.

Murtaza G, Azooz MM, Murtaza B, Usman Y, Saqib M. 2013. Nitrogen-Use-Efficiency (NUE) in plants under NaCl stress. In: Ahmad P, Azooz MM, Prasad MNVK, ed. Salt stress in plants. New York: Springer NY, 415-437.

Nie L, Feng J, Fan P, Chen X, Guo J, Lv S, Bao H, Jia W, Tai F, Jiang P. 2015. Comparative proteomics of root plasma membrane proteins reveals the involvement of calcium signalling in $\mathrm{NaCl}$-facilitated nitrate uptake in Salicornia europaea. Journal of Experimental Botany 66: 4497-4510 DOI 10.1093/jxb/erv216. 
491

492

493

494

495

496

497

498

499

500

501

502

503

504

505

506

507

508

509

Oaks A. 1993. Induction and turnover of nitrate reductase in Zea mays: Influence of $\mathrm{NO}^{3-}$. Plant Physiology 102: 1251-1257 DOI 10.1104/pp.102.4.1251.

Papadopoulos I, Rendig VV. 1983. Interactive effects of salinity and nitrogen on growth and yield of tomato plants. Plant and Soil 73, 47-57 DOI 10.1007/BF02197756.

Parul G, Kumar SA, Kumar TP. 2015. Abiotic stresses downregulate key genes involved in nitrogen uptake and assimilation in Brassica juncea L. Plos One 10: e0143645 DOI 10.1371/journal.pone.0143645.

Pessarakli M, Tucker T. 1988. Dry matter yield and nitrogen-15 uptake by tomatoes under sodium chloride stress. Soil Science Society of America Journal 52: 698-700 DOI 10.2136/sssaj1988.03615995005200030019x.

Popova OV, Dietz KJ, Golldack D. 2003. Salt-dependent expression of a nitrate transporter and two amino acid transporter genes in Mesembryanthemum crystallinum. Plant Molecular Biology 52: 569-578 DOI 10.1023/A:1024802101057.

Robinson PH, Grattan SR, Getachew G, Grieve CM, Poss JA, Suarez DL, Benes SE. 2004. Biomass accumulation and potential nutritive value of some forages irrigated with salinesodic drainage water. Animal Feed Science and Technology 111: 175-189 DOI 10.1016/S0377-8401(03)00213-X.

Rontein D, Basset G, Hanson AD. 2002. Metabolic engineering of osmoprotectant accumulation in plants. Metabolic engineering 4: 49-56 DOI 10.1006/mben.2001.0208. 
510 Sagi M, Dovrat A, Kipnis T, and Lips H. 1997. Ionic balance, bio-mass production, and 511 organic nitrogen as affected by salinity and nitrogen source in annual ryegrass. Journal of Plant Nutrition 20:1291-1316 DOI 10.1080/01904169709365336.

513

514

515

516

Sayed OH. 2003. Chlorophyll fluorescence as a tool in cereal crop research. Photosynthetica 41: 321-330 DOI 10.1023/b:phot.0000015454.36367.e2.

Shannon MC. 1997. Adaptation of plants to salinity. Advances in Agronomy 60, 75-120 DOI 10.1016/S0065-2113(08)60601-X.

Shenker M, Ben-Gal A, Shani U. 2003. Sweet corn response to combined nitrogen and salinity environmental stresses. Plant and Soil 256: 139-147 DOI 10.1023/A:1026274015858.

Siddiqui MH, Mohammad F, Khan MMA, Al-Whaibi MH. 2012. Cumulative effect of nitrogen and sulphur on Brassica juncea L. genotypes under $\mathrm{NaCl}$ stress. Protoplasma 249: 139-153 DOI 10.1007/s00709-011-0273-6.

Silveira JAG, Melo ARB, Viégas RA, Oliveira JTA. 2001. Salinity-induced effects on nitrogen assimilation related to growth in cowpea plants. Environmental and Experimental Botany 46: 171-179 DOI 10.1016/S0098-8472(01)00095-8.

Singh M, Singh VP, Prasad SM. 2016. Responses of photosynthesis, nitrogen and proline metabolism to salinity stress in Solanum lycopersicum under different level of nitrate supplementation. Plant Physiology and Biochemistry 109: 72-83 DOI 10.1016/j.plaphy. 2016.08.021. 
529 Song J, Ding X, Feng G, Zhang F. 2006. Nutritional and osmotic roles of nitrate in a 530 euhalophyte and a xerophyte in saline conditions. New Phytologist 171, 357-366 DOI 10.1111/j.1469-8137.2006.01748.x.

532

533

534

535

536

537

538

539

540

541

542

543

544

545

546

547

Soussi M, Ocaña A, Lluch C. 1998. Effects of $\mathrm{NaCl}$ on growth, photosynthesis and nitrogen fixation in chick-pea (Cicer arietinum L.). Journal of Experimental Botany 49: 1329-1337 DOI 10.1093/jexbot/49.325.1329.

Strasser BJ. 1997. Donor side capacity of photosystem II probed by chlorophyll a fluorescence transients. Photosynthesis Research 52, 147-155 DOI 10.1023/A:1005896029778.

Strasser RJ, Tsimilli-Michael M, Srivastava, A. 2004. Analysis of the chlorophyll a fluorescence transient. In Papageorgiou GC, Govindjee, ed. Chlorophyll a fluorescence, advances in photosynthesis and respiration. Netherlands: Spinger Dordrecht, 321-362.

Strasserf RJ, Srivastava A. 1995. Polyphasic chlorophyll a fluorescence transient in plants and cyanobacteria. Photochemistry and Photobiology 61: 32-42 DOI 10.1111/j.17511097.1995.tb09240.x.

Stirbet A, Riznichenko GY, Rubin AB, Govindjee. 2014. Modeling chlorophyll a fluorescence transient: Relation to photosynthesis. Biochemistry 79: 291-323 DOI 10.1134/S0006297914040014.

Sudmalis D, Silva P, Temmink H, Bijmans MM, Pereira MA. 2018. Biological treatment of produced water coupled with recovery of neutral lipids. Water Research 147: 33-42 DOI 
548

549

550

551

10.1016/j.watres.2018.09.050.

Todorova D, Katerova Z, Sergiev I, and Alexieva V. 2013. Role of polyamines in alleviating salt stress. In: Ahmad P, Azooz MM, and Prasad MNV, eds. Ecophysiology and responses of plants under salt stress. New York, NY: Springer New York, 355-379.

Villa M, Ulery A, Catalan-Valencia E, Remmenga M. 2003. Salinity and nitrogen rate effects on the growth and yield of Chile Pepper Plants. Soil Science Society of America Journal 67: 1781-1789 DOI 10.2136/sssaj2003.1781.

Wang H, Zhang M, Guo R, Shi D, Liu B, Lin X, Yang C. 2012. Effects of salt stress on ion balance and nitrogen metabolism of old and young leaves in rice (Oryza sativa L.). BMC Plant Biology 12: 194-194 DOI 10.1186/1471-2229-12-194.

Ward B. 2013. How nitrogen is lost. Science 341: 352-353 DOI: 10.1126/science.1240314.

Xu G, Fan X, Miller AJ. 2012. Plant nitrogen assimilation and use efficiency. Annual Review of Plant Biology 63: 153-182 DOI 10.1146/annurev-arplant-042811-105532.

Yusuf MA, Kumar D, Rajwanshi R, Strasser RJ, Tsimilli-Michael M, Govindjee, Sarin NB. 2010. Overexpression of $\gamma$-tocopherol methyl transferase gene in transgenic Brassica juncea plants alleviates abiotic stress: Physiological and chlorophyll a fluorescence measurements. Biochimica et Biophysica Acta 1797: 1428-1438 DOI 10.1016/j.bbabio.2010.02.002.

Zhao C, Zhang H, Song C, Zhu JK, Shabala S. 2020. Mechanisms of plant responses and 


\section{Figure 1}

Morphological parameters of annual ryegrass seedlings grown under different nitrogen and salt conditions.

Fig. 1. Morphological parameters of annual ryegrass seedlings grown under different nitrogen and salt conditions. The seeds of annual ryegrass were cultured in soil for one month, and the seedlings cut to the same height were then transferred into different nitrogen level $(2.0,5.0,10 \mathrm{mM})$ under $\mathrm{NaCl}(0,50,100 \mathrm{mM})$ stress in a hydroponic culture. After being grown for 10 days, the plant height and biomass were measured. (A) Images of seedlings at 10 days after transferred. (B) Plant height at 10 days after transferred. (C) The relative change of biomass ( $\%$ of biomass which was measured before treatment). Different letters above the columns indicate significant differences at $P<0.05$ by Student's $t$-test. 
A

$2.0 \mathrm{mM} \mathrm{N}$

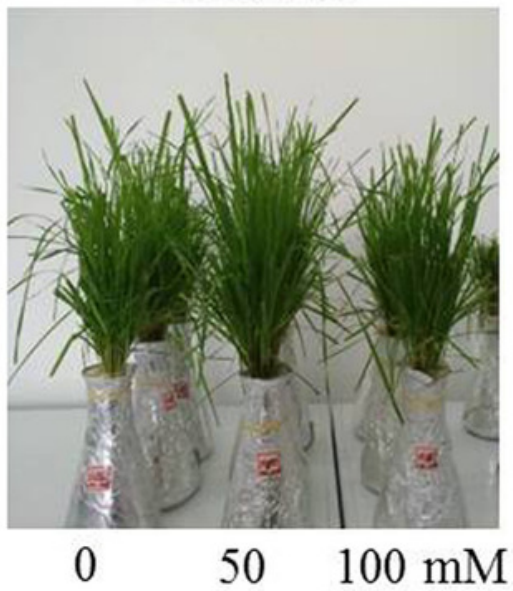

$5.0 \mathrm{mM} \mathrm{N}$

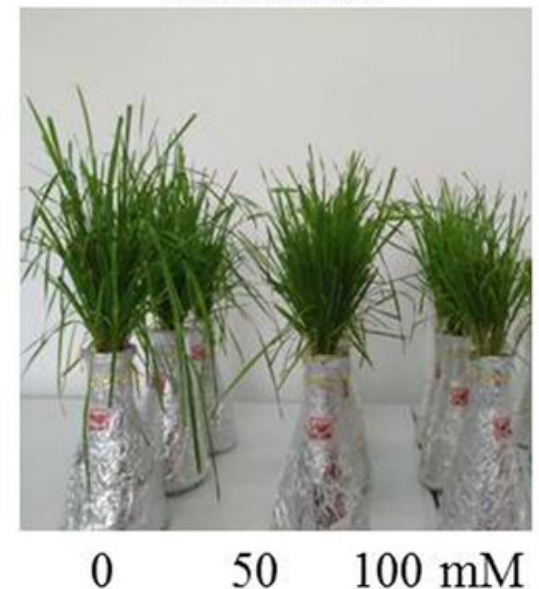

$10 \mathrm{mM} \mathrm{N}$

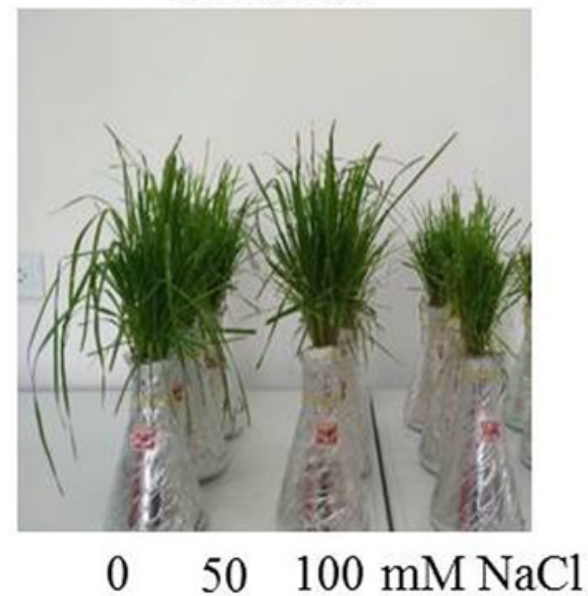

B $\quad 0 \mathrm{mM} \square 50 \mathrm{mM} \square 100 \mathrm{mM} \mathrm{NaCl} \quad \mathrm{C}$
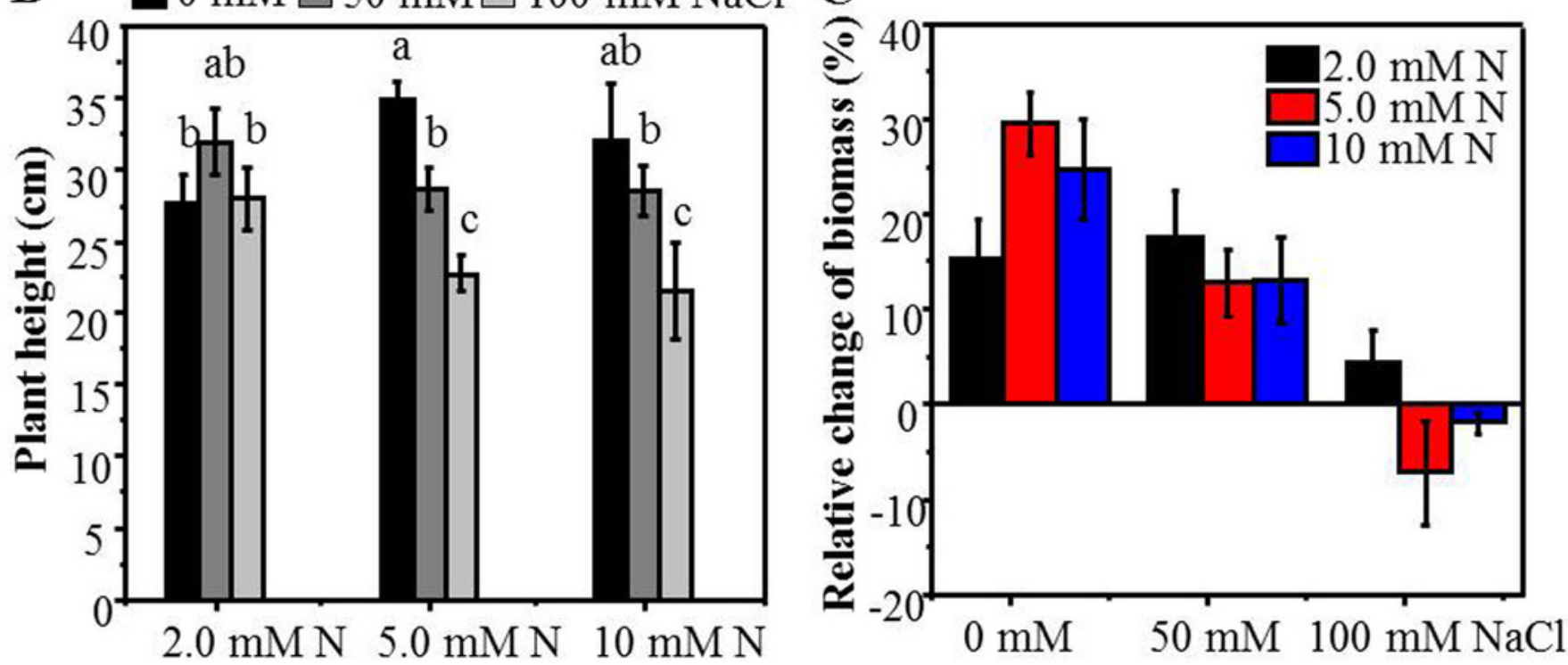


\section{Figure 2}

Alterations of chlorophyll fluorescence transients in leaves of annual ryegrass.

The annual ryegrass were grown with different nitrogen concentrations $(0.5,2.0,5.0 \mathrm{mM})$ under $0 \mathrm{mM}, 50 \mathrm{mM}$ (B), $100 \mathrm{mM} \mathrm{NaCl}$ (C) stress respectively. (D) Influence of nitrogen concentration on chlorophyll content under different levels of $\mathrm{NaCl}$ stress respectively. Different letters above the columns indicate statistically significant differences at $P<0.05$ by Student's t-test. 

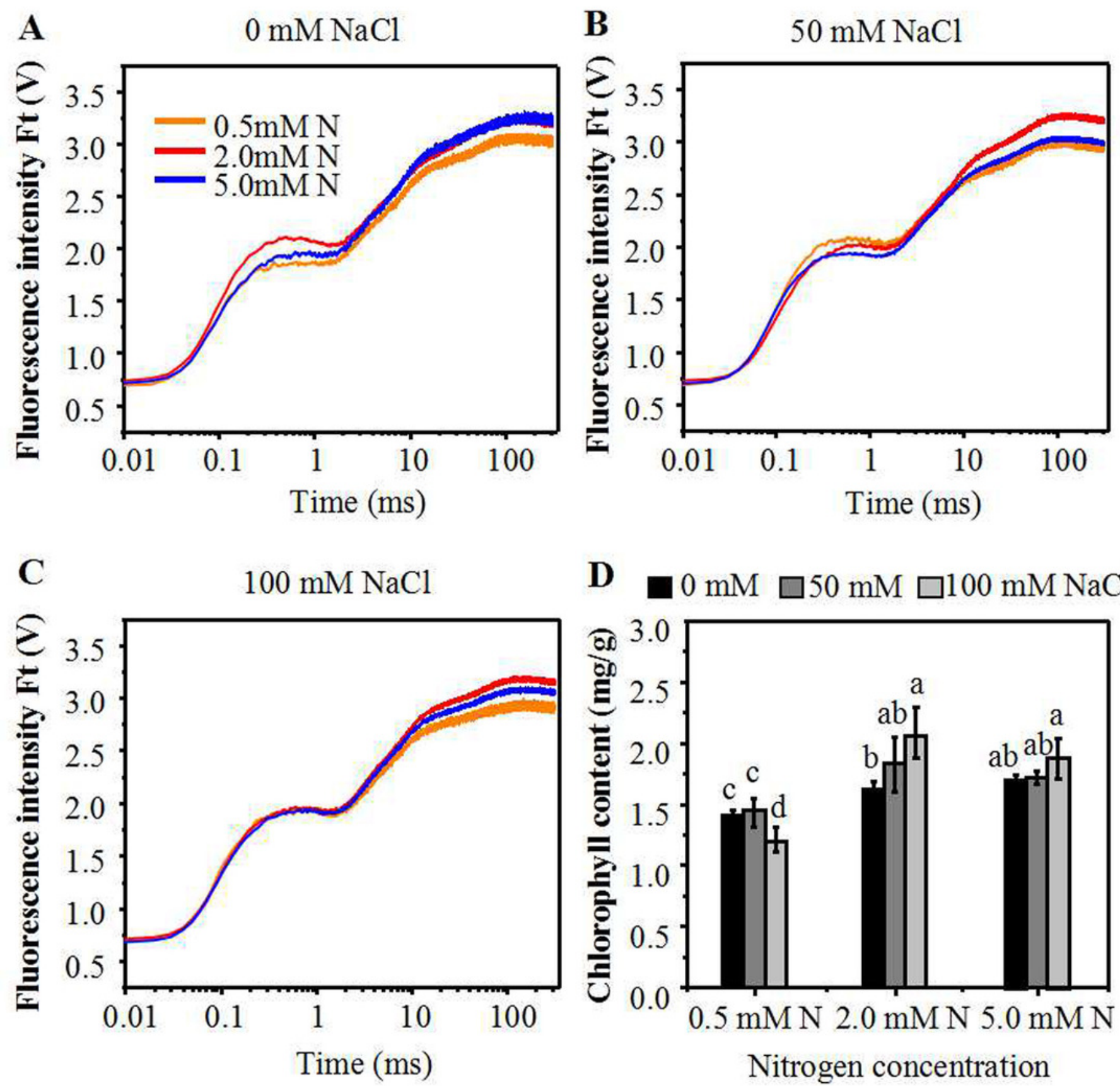

D $\square 0 \mathrm{mM} \square 50 \mathrm{mM} \square 100 \mathrm{mM} \mathrm{NaCl}$

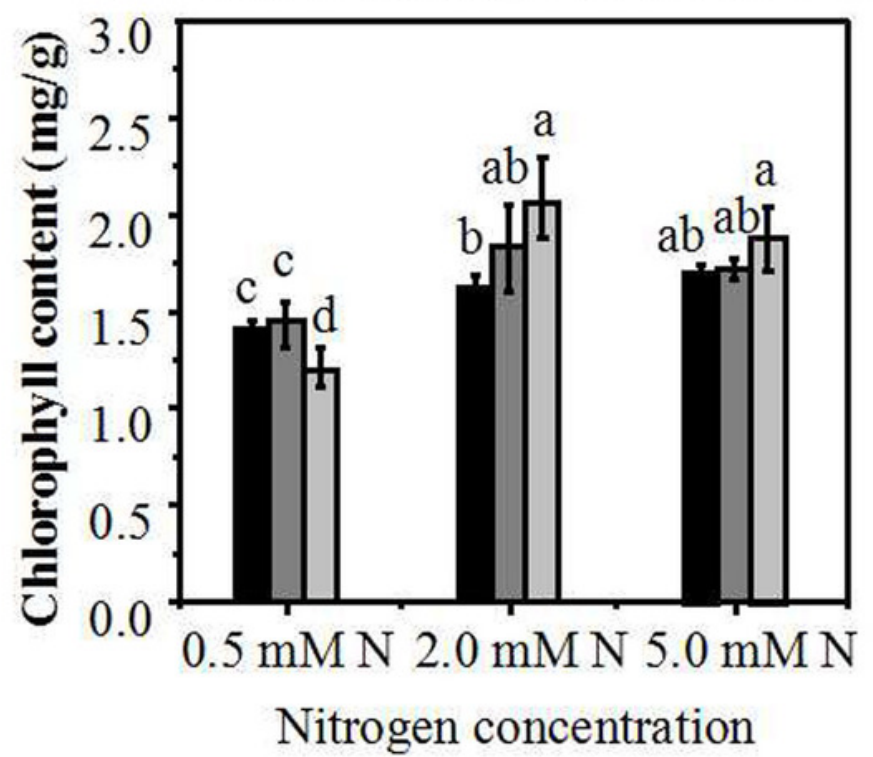




\section{Figure 3}

"Radar plots" of picked parameters characterizing influence of nitrogen concentration $(0.5,2.0,5.0 \mathrm{mM} \mathrm{N})$ on PS II of annual ryegrass.

The annual ryegrass leaves exposed to $0 \mathrm{mM}(\mathrm{A}), 50 \mathrm{mM}(\mathrm{B}), 100 \mathrm{mM}(\mathrm{C}) \mathrm{NaCl}$ stress respectively. All values are shown as percent of control. The parameters of plants grown under $0.5 \mathrm{mM}$ nitrogen concentration were set as control. Control=1. * indicate significant differences of Chlorophyll fluorescence parameters between different $\mathrm{N}$ levels at $P<0.05$ by Student's t-test under $0,50,100 \mathrm{mM} \mathrm{NaCl}$ respectively. 
A

\section{$0 \mathrm{mM} \mathrm{NaCl}$}

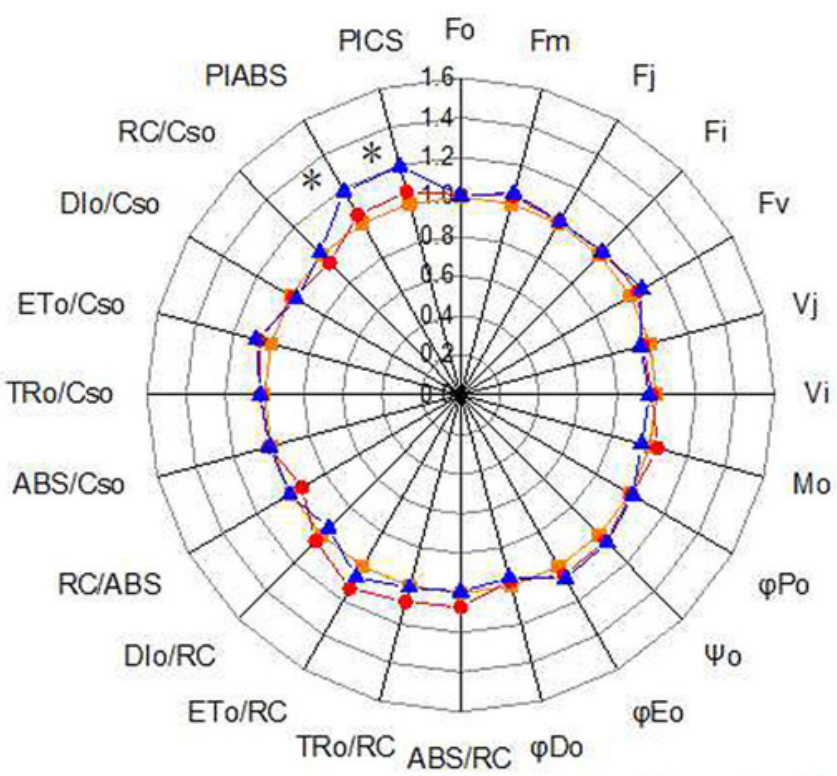

B

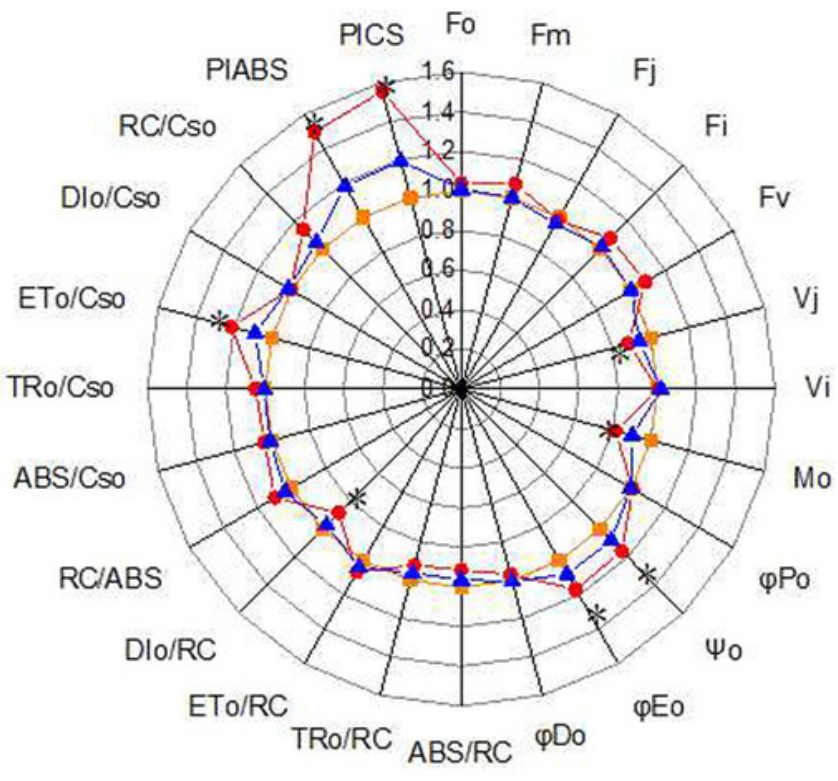

\section{C $\quad 100 \mathrm{mM} \mathrm{NaCl}$}

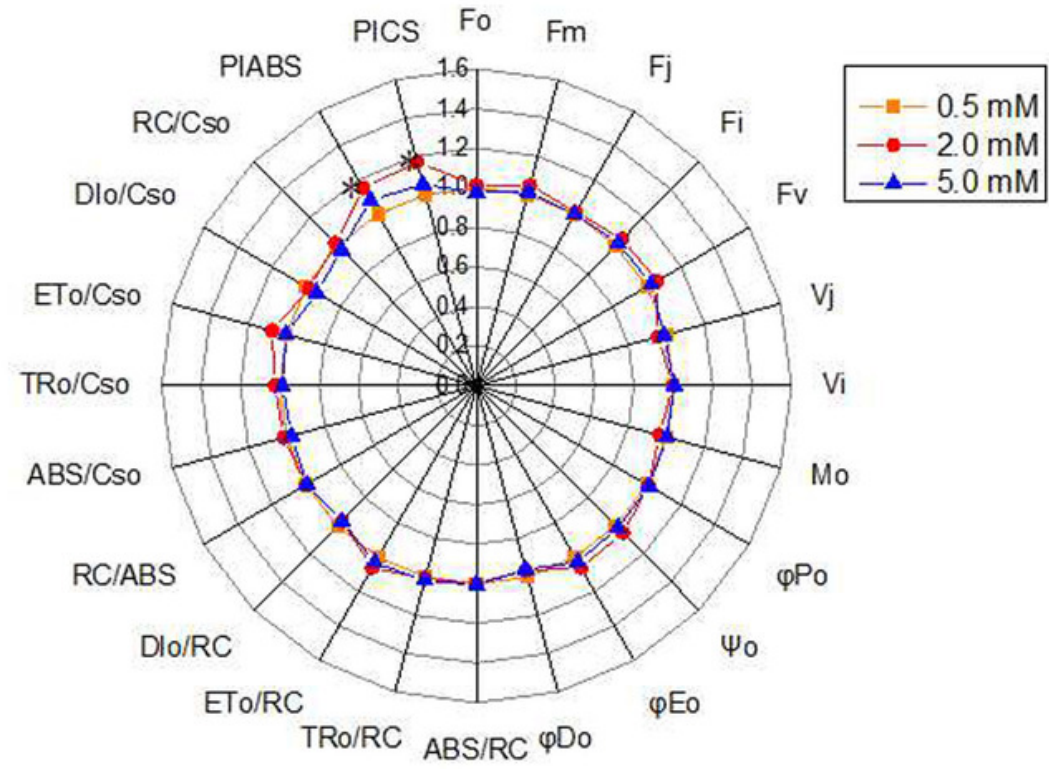


Figure 4

The membrane damage degree and antioxidant enzymes activities of the annual ryegrass leaves.

MDA content (A), EL (B), catalase (CAT) (C) or peroxidase (POD) (D) activity in the leaves of annual ryegrass grown with different nitrogen concentrations $(0.5,2.0,5.0 \mathrm{mM} \mathrm{N})$ exposed to different $\mathrm{NaCl}$ level $(0,50,100 \mathrm{mM} \mathrm{NaCl})$ respectively. Different letters above the columns indicate statistically significant differences at $P<0.05$ by Student's t-test. 
A

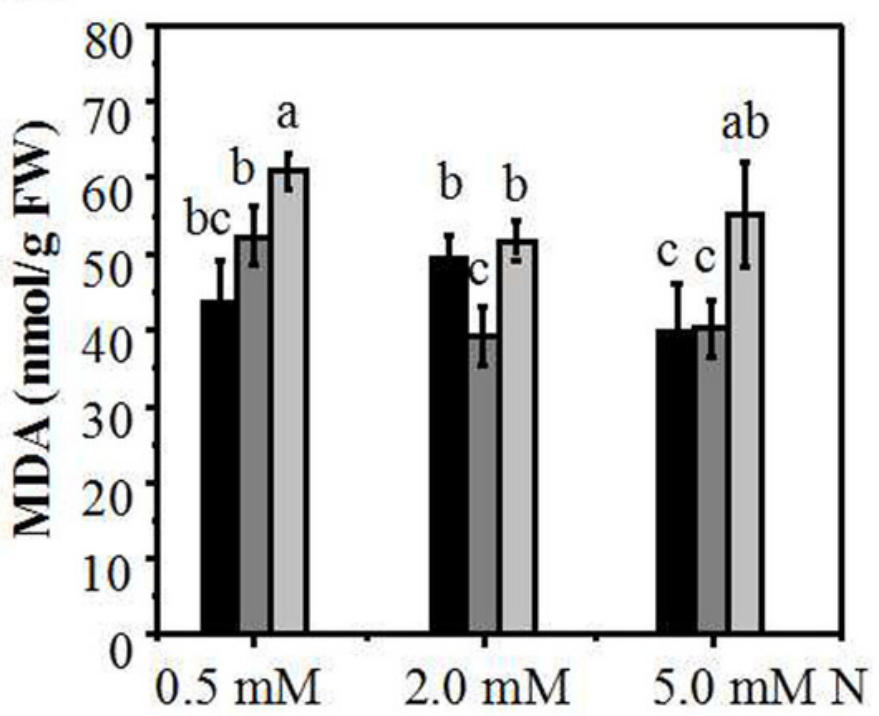

C

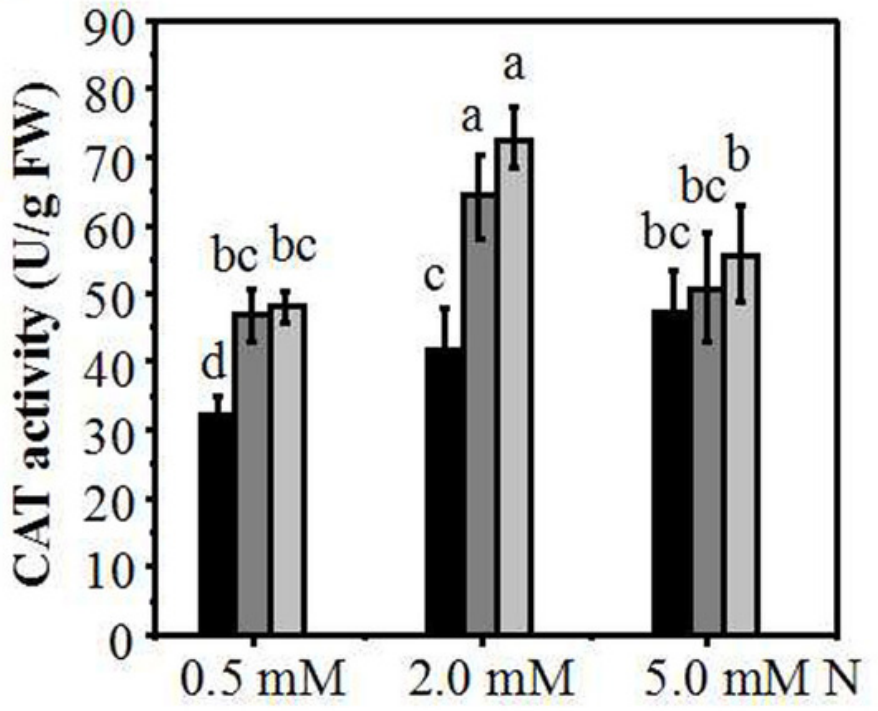

B $\square 0 \mathrm{mM} \square 0 \mathrm{mM} \square 100 \mathrm{mM} \mathrm{NaCl}$

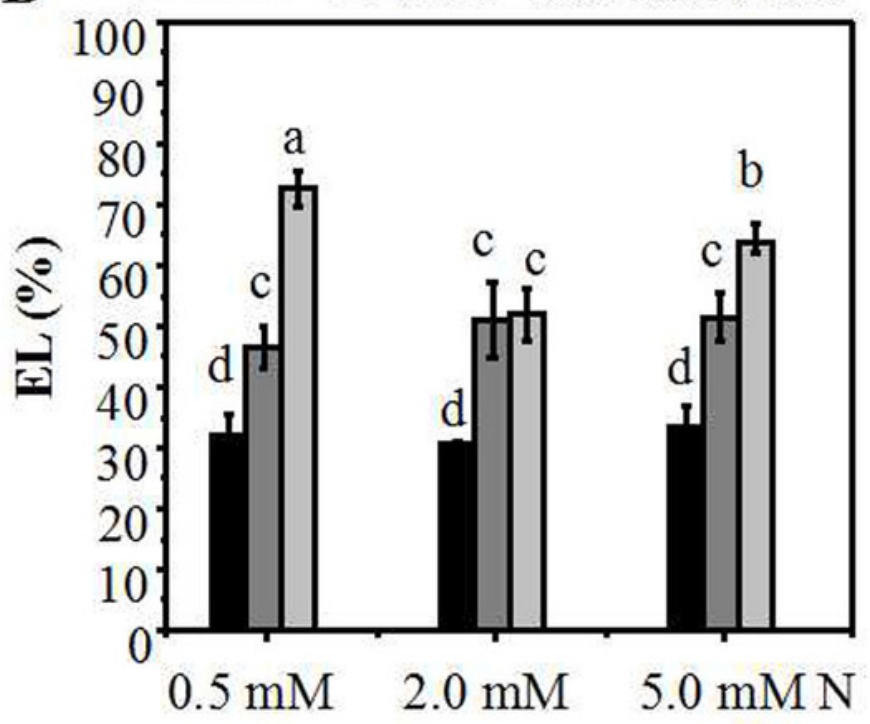

D

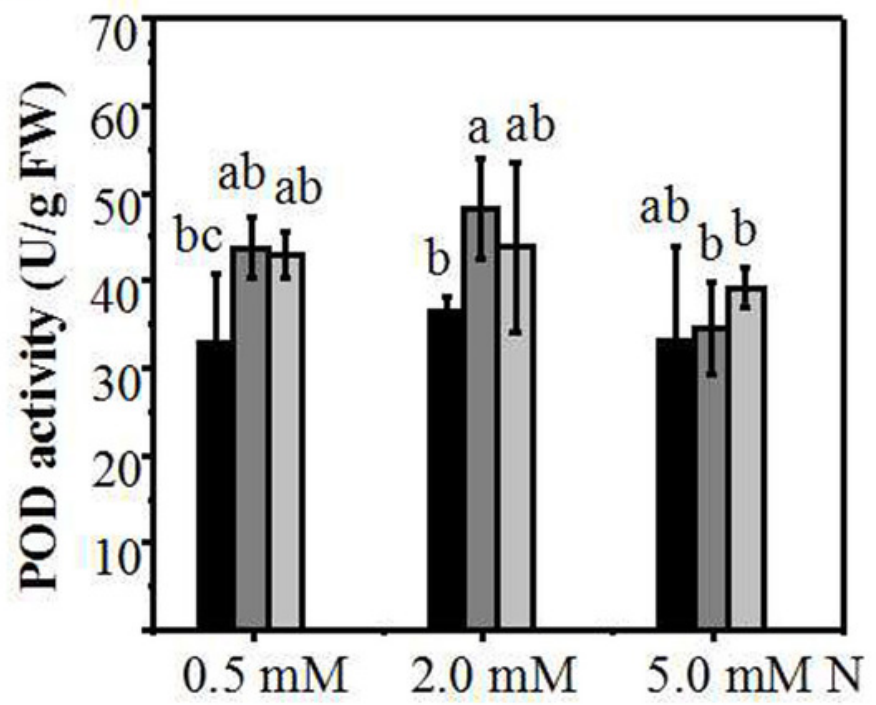




\section{Figure 5}

Relative expression of $\mathrm{N}$ metabolism-related genes and nitrogen content of leaves grown under different conditions.

(A) NR expression in the leaves of annual ryegrass grown under different nitrogen concentration $(2.0,5.0 \mathrm{mM})$ exposed to different salt stress for 12 hours $(0,50,100 \mathrm{mM}$ $\mathrm{NaCl}$ ) respectively; (B) Nitrogen content of leaves grown with different nitrogen concentrations exposed to different salt stress for 10 days respectively. Different letters above the columns indicate statistically significant differences at $P<0.05$ by Student's t-test.

A

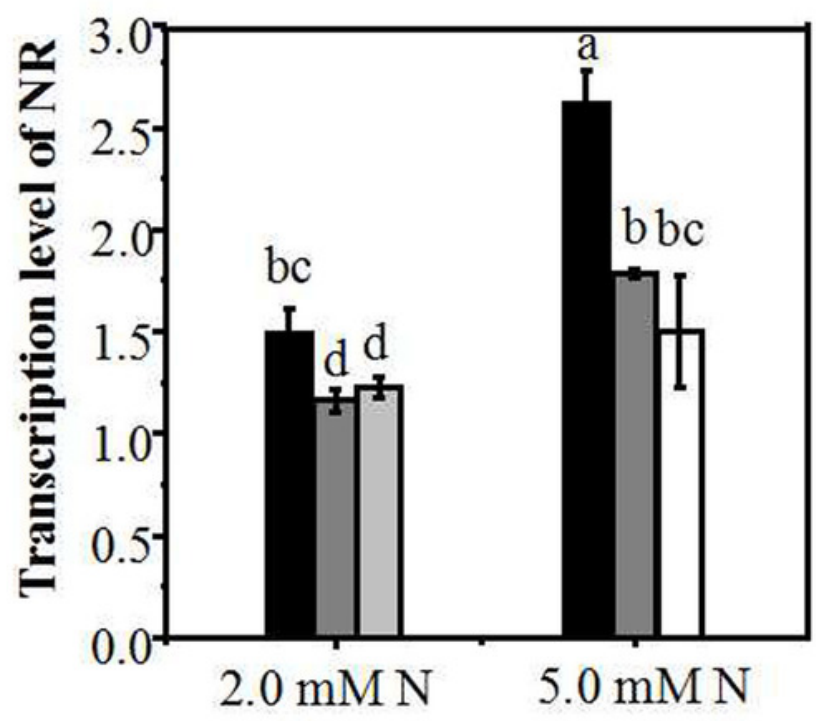

B $\square \mathrm{mM} \square 50 \mathrm{mM} \square 100 \mathrm{mM} \mathrm{NaCl}$

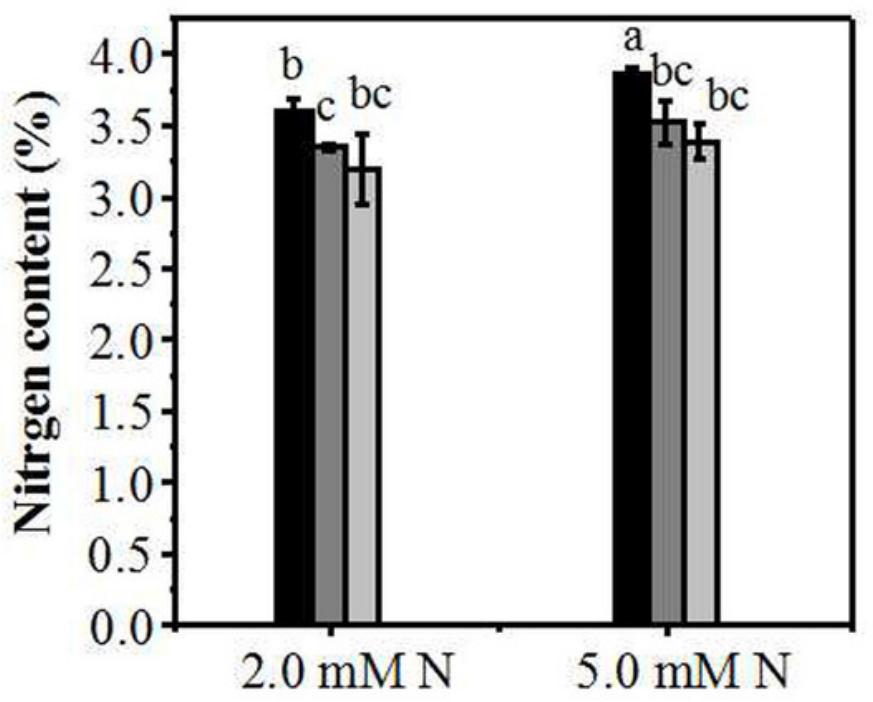

